\title{
The Implementation of Preventive Vaccination of Dogs and Cats against Rabies in Rural Areas
}

\author{
Witold Kołłątaj (Corresponding author) \\ III Chair of Paediatrics, Department of Paediatric Endocrinology, Medical University of Lublin, ul. \\ Chodźki 2, Lublin 20-093, Poland \\ Tel: 48-81-7185-440Ｅ-mail: w.kollataj@umlub.pl \\ Andrzej Milczak
}

Faculty of Veterinary Medicine University of Life Sciences in Lublin, ul. Akademicka 13

Lublin 20-095, Poland

Tel: 48-81-445-6180Ｅ-mail: tatotiny@o2

Barbara Kołłątaj

Chair and Department of Epidemiology, Medical University of Lublin, ul. Chodźki 2

Lublin 20-093, Poland

Tel: 48-81-742-3768Ｅ-mail: bk@data.pl

\begin{abstract}
Marian Sygit
Department of Health Education, University of Szczecin, Al. Piastów 40b bl. 6

Szczecin 71-065, Poland

Tel: 48-512-209-310
\end{abstract}

$\&$

Institute of Rural Health in Lublin, ul. Jaczewskiego 2

Lublin 20-090, Poland

Tel: 48-81-718-4400Ｅ-mail: ksygit@poczta.onet.pl

Katarzyna Sygit

Department of Health Education, University of Szczecin, Al. Piastów 40b bl. 6

Szczecin 71-065, Poland

Tel: 48-512-209-310Ｅ-mail: ksygit@poczta.onet.pl

Received: October 8, 2011

Accepted: October 27, $2011 \quad$ Published: January 1, 2012

doi:10.5539/ep.v1n1p20

URL: http://dx.doi.org/10.5539/ep.v1n1p20

\begin{abstract}
Rabies is a fatal viral infection that has no specific treatment. For that reason prevention, especially vaccinations against rabies, is the matter of the utmost importance.

The study involved 176 dog owners (possessing 257 dogs) and 86 cat owners (possessing 182 cats) from rural areas in Lublin province. The special original inquiry questionnaire was applied.

Results: Preventive vaccination of dogs against rabies is properly realized by only $64.8 \pm 7 \%$ dog owners (below the level recommended by WHO) and by only $19.8 \pm 9.1 \%$ of cat owners - inhabitants of rural areas in Lublin
\end{abstract}


Province. $16.5 \%$ of respondents confessed that they have never vaccinated their dogs against rabies. $48.3 \pm 7.4 \%$ of dog owners as well as $65.1 \pm 10.1 \%$ of cat owners don't have any veterinary health certificates for their animals.

Conclusions: The standards of veterinary care as well as effectiveness of dogs and cats vaccinations against rabies in rural areas in Poland need to be improved.

Keywords: Rabies, Cats, Dogs, Vaccination, Negligence, Rural regions, Risk

\section{Introduction}

Rabies is a fatal viral infection, usually acquired in humans from the bite of infected carnivores (meat-eating animals). The virus can also be spread by getting the virus-laden saliva in an open wound, splashed in an eye, or other mucous membrane, such as the mouth. A rare method of transmission is via aerosol (this can happen in a cave housing infected bats that aerosolize saliva during giving out high-pitched sounds).

The dangers to human pose not only ill animals but also carriers of asymptomatic rabies (Fekadu, 1991, pp.191-198).

Worldwide, more than 55000 people die of rabies every year. Every year, more than 15 million people worldwide receive a post-exposure preventive regimen to avert the disease (WHO, 2010). In Poland, the last case of rabies infection in humans was reported in 2002.

Rabies occurs in more than 150 countries and territories. It is prevalent in all the continental regions of Asia, America and Africa, Greenland and many countries in Europe.

Scandinavia (except Southern Jutland in Denmark) as well as the British Isles, Japan, Australia and New Zealand are rabies free.

In countries where domestic animals are not vaccinated against rabies, dogs are the source of $99 \%$ of human rabies deaths (Shepherd, 2001, pp.839-849; WHO, 2010). In European countries where domestic animals vaccinations are realized in insufficient way, foxes and bats pose danger to humans. In countries where domestic animals are vaccinated and the fox population is tightly controlled, bats are the main source of infection (Calisher, 2006, pp.531-545; Lina, 2001, pp.245-254). Cats, dogs and cattle account for nearly 90 percent of rabies cases in domestic animals. Although people usually associate rabies with dogs, among domesticated animals in the U.S. and in European countries rabies today is more likely to be found in cats.

In Poland rabies is still present in wild environment. Wild mammals, including badgers, raccoons, foxes and bats but also rodents as well as hares are important as reservoirs for the disease (Łyczak, 2001, pp.131-135; Tomasiewicz, 2006, pp.337-340). In 2001, there were reported 3037 cases of animal rabies (Sadkowska-Todys, 2003, pp.139-148) in the territory of Poland, in 2007 - 70 cases: 42 foxes, 7 raccoon dogs, 6 farm fur (-covered) animals, 6 cats, 3 dogs, 3 bats, 1 badger, 1 weasel and 1 marten (Sadkowska-Todys, 2009, pp.257-261). In 2010, when the epidemiological situation has worsened in flooded areas, just only in Sąeckie, Gorlice and Limanowa districts there have been noticed 33 new cases of rabies in wild mammals (mainly foxes).

There is no specific treatment for rabies infection. For that reason prevention, especially vaccinations against rabies, is the matter of the utmost importance (Rupprecht, 2006, pp.1021-1038; WHO, 2011).

In Poland, since 1949, such vaccinations are required by law. The vaccination concerns wild animals (oral rabies vaccines for animals living in wild environment - mainly foxes and stray dogs), domestic dogs as well as humans (people are vaccinated in cases of risky contacts with infected animals). In Poland, like in many countries and the U.S. states, the vaccination of cats is not required by law but is recommended.

\section{Aim}

The aim of this study was to determine rabies vaccination status of domestic cats and dogs living in rural areas of selected districts in Lublin Province (Poland).

\section{Material and Methods}

The study involved 176 dog owners (possessing in total 257 dogs) and 86 cat owners (possessing 182 cats) from rural areas of Bełżyce, Poniatowa, Opole Lubelskie and Chodel districts in Lublin province (Poland).

They represented both the purebred and not purebred dog and cat owners who possessed such animals for pleasure and companionship (pets), as well as for farming purposes.

Selection of the owners was random and included individuals who because of their health status were patients of outpatient clinics in Poniatowa (Lublin province, Poland). 
A special original inquiry questionnaire with questions concerning details of residence, education and professional status of dog and cat owners, aspects of animals breeding, veterinary care, veterinary health certificate possession, vaccinations and aspects of animal-humans coexistence as well as dogs and cats freedom of movement around the house and the surrounding area was applied.

The survey was carried out during the period: January 2011 - May 2011 and was based on survey feedback issued during visit in the outpatient clinics and received during subsequent visits to clinics.

\subsection{Statistical Methods}

All obtained data were presented in tables as both absolute numbers and as percentages.

If it was necessary, obtained percentage values were supplemented by calculated confidence intervals ( 95 percent confidence intervals for proportions).

While comparing proportions (percentages) the Chi square test was used.

Significance was accepted as a p-value of less than 0.05 .

\section{Results}

The obtained data are presented below as tables (Tables 1-4) and figures (Figures 1-2).

Preventive vaccination of dogs against rabies is properly realized by only $64.8 \%$ of polled owners $(64.8 \pm 7 \%$; $95 \%$ confidence limits) - table 1, figure 1. Excluding pet owners (possessing dogs with free movement restricted only to living quarters), the proper preventive vaccination is realized by only $(114-26) /(176-35)$, that is $62.4 \%$ (62.4 $\pm 8 \% ; 95 \%$ confidence limits) of polled.

$16.5 \%$ of respondents $(16.5 \pm 5.5 \%$; $95 \%$ confidence limits $)$ confessed that they have never vaccinated their dogs against rabies.

Preventive vaccinations of cats against rabies are not required by Polish law so it is obvious that they are realized less frequently than vaccinations of dogs (figure 1), especially since such immunizations are paid for.

The results presented in table 2 suggest that only $19.8 \%$ of cat owners realize proper their cats immunization against rabies (19.8 $\pm 9.1 \%$; $95 \%$ confidence limits).

$47.7 \%$ of respondents $(47.7 \pm 10.6 \%$; $95 \%$ confidence limits) confessed that they have never vaccinated their cats against rabies.

While excluding pet owners (table 2, row "only living quarters") one can notice that $41 /(86-10)=41 / 76$, that is $53.9 \%$ (53.9 $\pm 11.2 \%$; $95 \%$ confidence limits) owners of cats allowed to move outside living quarters (possible contacts with wild and stray animals) have never vaccinated their cats against rabies.

Veterinary health certificates are incontrovertible evidences proving veterinary care over animals.

The lack of such certificates may suggest that in rural areas still live non registered animals. Many of such animals will probably stay unregistered and unvaccinated even in any cases of epidemic hazards.

The data presented as table 3 suggest that $48.3 \%$ (48.3 $\pm 7.4 \%$; $95 \%$ confidence limits) of dog owners don't care about the health of their animals (no veterinary health certificates means no veterinary care).

While excluding pet owners (table 3, row "only living quarters") one can notice that (85-10)/(176-35), that is $53.2 \%$ (53.2 $\pm 8.2 \%$; $95 \%$ confidence limits) of dog owners allowed to move outside living quarters (possible contacts with wild and stray animals) don't care of veterinary health certificates.

The attitude of owners towards proper veterinary care of possessed cats is exemplified by data presented in the table 4 and figure 2 .

$65.1 \%$ of cat owners $(65.1 \pm 10.1 \% ; 95 \%$ confidence limits) do not posses any veterinary certificates for their animals.

Instead of the fact that percentages of cat and dog owners towards veterinary care seem to be not quite similar $(65.1 \pm 10.1 \%$ - table 4 versus $48.3 \pm 7.4 \%$ - table 3$)$, the difference between fractions is not statistically significant while assuming $\alpha=0.05$ (Chi square $=1.91, \mathrm{df}=1 ; \mathrm{p}=0.167$ ).

This same conclusion may be drawn while excluding pets (dogs and cats allowed to move only over living quarters) owners (Chi square $=0.84, \mathrm{df}=1 ; \mathrm{p}=0.358$ ). 


\section{Discussion}

Rabies is a vaccine-preventable disease. Vaccinating the entire human population against rare disease isn't practical, on the other hand it may be potentially dangerous to some people such as to young chidren, elderly people and immunocompromised ones (Manning, 2008, pp.1-28; Shepherd, 2001, pp.839-849).

The most cost-effective strategy for preventing rabies in people consists in eliminating rabies in wild and stray animals through vaccinations, restrict the population of foxes and shooting potentially infected ananimals as well as vaccinating domestic animals - mostly dogs, in some countries dogs and cats (Rupprecht, 2006, pp.1021-1038).

Lack of complete vaccine coverage increases the risk of disease appearance for the entire animal population and poses the potential danger to human beings.

Such danger increases in cases of incomplete vaccinations and non-uptake of immunizations (improper scheme of vaccinations, owners or veterinary doctors negligence), too.

Obtained data presented in tables 1-4 suggest that rural regions in Poland are the areas where domestic animals immunization status and veterinary care pose a potential danger to humans.

\subsection{Preventive Vaccination of Dogs against Rabies}

Preventive vaccination of dogs against rabies is properly realized by only $64.8 \%$ of polled owners $(64.8 \pm 7 \%$; $95 \%$ confidence limits). Taking into consideration that in rural regions in Lublin province there are no less than 370000 households (GUS, 2002) and that 50 per cent of rural households have dogs (TNS OBOP, 2002, pp.1-4), the simple calculations suggest the presence of at least 52000 - 78000 dogs (not including stray and wild ones) not immunized against rabies or improperly vaccinated - that is susceptible to rabies virus. When considering that many rural owners possess more than $1 \mathrm{dog}$, such number may be close to 100000 or even higher.

Despite such calculations, when comparing obtained data to some official recommendations, vaccination coverage in the total domestic dog population living in rural regions in Poland seems to be not so bad. To prevent rabies epidemics, WHO suggests that the total dog population vaccination level should remain at or above $80 \%$ (WHO, 2007). In some industrialized countries, such as Japan, local veterinary services suggest that the regular vaccination should concern $70 \%$ of dogs (Takayama, 2000, pp.93-97), in poor rural African countries such as Kenya and Tanzania the immunization coverage of dog population required to prevent outbreaks of dog rabies is estimated at 59-70 \% (Cleaveland, 2003, pp.1965-1973; Kitala, 2002, pp.215-222). Against such background of immunization targets, the obtained above data (preventive vaccination of dogs against rabies is properly realized by $64.8 \%$ of polled owners) seem to be rather optimistic. But when one thinks with reference to the total rural dog population (in rural regions in Poland there almost 1000000 stray and unsupervised dogs (Polski Związek Łowiecki, 2011)), such data should be recalculated and percentage values will be not so satisfactory.

Mentioned problem needs to be further investigated.

Dogs are considered as the most common domestic rabid animals worldwide (Rupprecht, 2006, pp.1021-1038). Such opinion is determined by long-term epidemiological observations but in some conditions and in some countries it is no longer current. Vaccinations of dogs have reduced the number of human (and animal) rabies cases in several countries, particularly in Latin America and Europe. In some countries social and cultural changes lead to re-define the term domestic animal. People used to breed not only dogs and cats but wild animals (such as fur-covered ones), too. Nowadays, among pets we can find lizards, snakes, badgers, ferrets, weasels, squirrels and many animals considered as exotic and/or wild ones. This allows people to come into close contact with those animals that have been considered as not present in human environment. Some of them are vulnerable to rabies virus; some owners allow them a great deal of freedom.

As the effect of such changes, the last epidemiological statistics suggest that among 70 animal cases of rabies in Poland (in 2007) there were only 3 rabid dogs but 6 rabid cats, 42 rabid foxes, 7 ill raccoon dogs and 6 infected farm fur animals (Sadkowska-Todys, 2009, pp.257-261).

\subsection{Preventive Vaccination of Cats against Rabies}

The data obtained by the help of used questionnaire should be valuable contribution to the discussion on rabies in Poland and eventual changes in Polish law. In Poland, since 1949, vaccinations of dogs are required by law. The vaccination of cats is not required but is recommended, meanwhile in 2007 there were 2 times more cases of cat rabies than cases of rabid dogs (Sadkowska-Todys, 2007, pp.257-261). 
The rabies vaccination of cats living in rural areas is not very popular. The data presented in table 2 suggest that only $19.8 \%$ of cat owners properly realize their cats' immunization against rabies $(19.8 \pm 9.1 \% ; 95 \%$ confidence limits).

Taking into consideration that in rural regions in Lublin province there are no less than 370000 households (GUS, 2002) and that 30 percent of rural households have cats - usually 2 or more (TNS OBOP, 2002), one may come to the conclusion that in such area there are no less than 160000 - 2000000 cats (not including stray ones) being not immunized against rabies or improperly vaccinated - that means: susceptible to rabies virus. There is obvious, that cats living in rural areas are usually allowed more deal of freedom than dogs so they are more exposed to contacts with infected animals.

There is another worthy noticing reason for paying special attention to cats and their potential role in rabies epidemics. Some cats can live with the virus for years, show no symptoms (carriers of asymptomatic rabies) but still be able to pass the infection to other mammals (including humans) by direct contact (Tepsumethanon, 2004, pp.278-280). Such facts should be important arguments for applying for changes in Polish law and vaccinating cats against rabies.

When one adds the numbers of not immunized or improperly vaccinated cats and dogs living in rural regions in Lublin province, the sum will be in between 200000 - 280000 . Such number means the potential threat to humans in cases of any presences of rabies foci in our region.

\subsection{The Epidemiological Situation of Rabies in Poland and Surrounding Countries - Legislative and Organisational Challenge}

For some years there have been observed good trends in the epidemiological situation of rabies in Poland. In 2001 - 3037 cases of animal rabies (Sadkowska-Todys, 2003, pp.139-148), in 2007 - only 70 cases. But sudden climatic changes, episodes of flood (in 2010) causing migrations of wild animals have worsened situation in flooded areas - for example 108 cases of rabies just only in Małopolskie province (PAP, 2011). Because of the fact that unpredictable situations may provoke wild animals migrations as well as make problems with routine wild foxes vaccinations, epidemiological situation of rabies in Poland must be considered as possible to destabilize.

The epidemiological situation of rabies in Europe is still unstable. Almost all countries in Europe annually report new cases of rabies in wild animals. It is surely tightly connected with the problem of carrier state in wild animals. The list of wild carrier hosts includes, among others, bats and foxes (Aguilar-Setien, 2005, pp.517-522; Baer, 1967, pp.82-90).

From 1977 to 2006, a total number of 831 cases of bat rabies were detected in Europe. The majority of virus-positive bats originated from Denmark, followed by the Netherlands, Germany and Poland counting for more than 90 percent of all virus-positive bats recorded for this time period (Müller, 2007, pp.273-288; WHO, 2011). Bat rabies was also reported in other countries being neighbours of Poland such as the Czech Republic, Slovakia, the Ukraine and Russia (Helesic, 2007, pp.93-98; Shepherd, 2001, pp.839-849; WHO, 2011).

Taking into consideration the truisms that wild animals don't respect land borders and may migrate all over different countries, the epidemiological problems present in one European country pose health risks to people living in other countries.

Meanwhile, the epidemiological situation in Poland may be described as follows: the population of humans is susceptible to the rabies infection and most cats as well as dogs living in rural areas are susceptible too (not vaccinated or vaccinated in improper way). The number of stray and unsupervised cats as well as dogs, being exposed to contacts with wild animals and posing a danger of transmitting rabies from wild animals to domestic ones, is considerable - roughly estimated numbers in Poland: almost 300000 stray dogs and almost 700000 unsupervised ones, more than 650000 stray cats (Polski Związek Łowiecki, 2011). Both in our country as well as in neighbouring countries one can find wild animals that are rabies carriers. The statistics concerning prevalence of rabies carriers among healthy domestic and wild animals are unavailable. The number of rabies cases among wild animals has increased recently.

Such facts should be valuable contribution to the discussion on the subjects of law regulations, adherence to law rules, practical aspects of veterinary care over domestic animals as well as on the subjects of the problems of stray and unsupervised animals and practical aspects of vaccinations against rabies in Poland.

\section{Conclusions}

1) Rabies vaccination coverage in rural dogs and cats populations is not satisfactory. 
2) Taking into consideration both free movement allowance and immunization status, cats may pose high hazard to people in cases of rabies foci appearance.

3) The common lack of veterinary certificates may suggest that there are lots of non-registered (and surely unvaccinated) animals living in rural areas.

4) The standards of veterinary care as well as effectiveness of dogs and cats vaccinations against rabies in rural areas in Poland need to be improved.

\section{References}

Aguilar-Setien, A. et al. (2005). Salivary excretion of rabies virus by healthy vampire bats. Epidemiol Infect., 133(3), 517-522. http://dx.doi.org/10.1017/S0950268805003705

Baer, G. M., \& Bales L. G. (1967). Experimental rabies infection in the Mexican freetail bat. J Infect Dis., 117, 82-90. http://dx.doi.org/10.1093/infdis/117.1.82

Calisher, Ch. H. et al. (2006). Bats: Important Reservoir Hosts of Emerging Viruses. Clin Microbiol Rev., 19, 531-545. http://dx.doi.org/10.1128/CMR.00017-06

Cleaveland, S. et al. (2003). A dog rabies vaccination campaign in rural Africa: impact on the incidence of dog rabies and human dog-bite injuries. Vaccine., 21(17-18), 1965-1973. http://dx.doi.org/10.1016/S0264-410X(02)00778-8

Fekadu, M. (1991). Latency and aborted rabies. In: Baer, G. M. (ed.): The natural history of rabies. Boca Raton, Florida: CRC Press, 191-198.

GUS. (2002). Gospodarstwa domowe i rodziny. GUS [Online] Available: www.stat.gov.pl/cps/rde/xbcr/lublin/ASSETS (August 25, 2011).

Helesic, J., Bartonícka, T., \& Krbková, L. (2007). [Bat rabies in Europe and the Czech Republic]. [Article in Czech]. Klin Mikrobiol Infekc Lek., 13, 93-98.

Kitala, P. M. et al. (2002). Comparison of Vaccination Strategies for the Control of Dog Rabies in Machakos District, Kenya. Epidemiol Infect., 129, 215-222. http://dx.doi.org/10.1017/S0950268802006957

Lina, P. H. \& Hutson, A. M. (2001). Bat rabies in Europe: a review. Dev Biol (Basel), 125, 245-254.

Łyczak, A. et al. (2001). Epizootic situation and risk of rabies exposure in Polish population in 2000, with special attention to Lublin province. Ann Agric Environ Med., 8, 131-135.

Málaga-Alba, A. (1954). Vampire bat as a carrier of rabies. Am J Public Health., 44, 909-918. http://dx.doi.org/10.2105/ AJPH.44.7.909

Manning, S. E. et al. (2008). Human rabies prevention--United States, 2008: recommendations of the Advisory Committee on Immunization Practices. MMWR Recomm Rep., 57, 1-28.

Müller, T. et al. (2007). Epidemiology of bat rabies in Germany. Arch Virol., 152, 273-288. http://dx.doi.org/10.1007/s00705-006-0853-5

PAP. (2011). Małopolskie: 108 przypadków wścieklizny wśród zwierząt w 2010 r. Money.pl. [Online] Available: http://www.money.pl (August 25, 2011).

Polski Związek Łowiecki. (2011). Szkody wyrządzane przez psy i koty w polskich łowiskach. Brać Łowiecka. [Online] Available: http://www.braclowiecka.net.pl/media/pdf/psyoprac.pdf (August 25, 2011).

Rupprecht, C.E., Willoughby, R., \& Slate, D. (2006). Current and future trends in the prevention, treatment and control of rabies. Expert Rev Anti Infect Ther., 4(6), 1021-1038. http://dx.doi.org/10.1586/14787210.4.6.1021

Sadkowska-Todys, M., Czerwiński, M., \& Łabuńska, E. (2003). Wścieklizna w 2001 roku. Przegl epidemiol., 57, 139-148.

Sadkowska-Todys, M., \& Kucharczyk, B. (2009). Wścieklizna w Polsce w 2007 roku. Przegl epidemiol., 63, 257-261.

Shepherd, J. E., \& Grabenstein, J. D. (2001). Immunizations for High-Risk Populations: Vaccinations for Immunocompromised Patients. J Am Pharm Assoc., 41(6), 839-849.

Takayama, N. (2000). Rabies control in Japan. Jpn J Infect Dis., 53, 93-97.

Tepsumethanon, V. et al. (2004). Survival of naturally infected rabid dogs and cats. Clin Infect Dis., 39, 278-280. http://dx.doi.org/10.1086/421556 
TNS OBOP. (2002). Co Polacy posiadaja. Warszawa: Omnimas.

Tomasiewicz, K. et al. (2006). Post-exposure anti-rabies prophylaxis in Lublin Provence (Eastern Poland) in 2004-2005. Ann Agric Environ Med., 13, 337-340.

WHO. (2010). Rabies Fact Sheet $\mathrm{N}^{\circ} 99$ Updated September 2010. [Online] Available: http://www.who.int/mediacentre/factsheets/fs099/en/ (August 25, 2011).

WHO. (2007). Oral vaccination of dogs against rabies Guidance for research on oral rabies vaccines and Field application of oral vaccination of dogs against rabies. Geneva: WHO.

WHO. (2011). Rabies - Bulletin - Europe Rabies Information System of the WHO Collaboration Centre for Rabies Surveillance and Research. FLI, IfE 2006-2010. [Online] Available: http://rbe-new.fli.bund.de/About_Rabies/Bats (August 25, 2011).

Zinsstag, J. et al. (2007). Human benefits of animal interventions for zoonosis control. Emerg Infect Dis., 13(4), 527-531. http://dx.doi.org/10.3201/eid1304.060381

Table 1. Preventive vaccination of dogs against rabies in context to their living space

\begin{tabular}{|c|c|c|c|c|c|c|c|c|c|c|}
\hline $\begin{array}{c}\text { Dog's living space. } \\
\begin{array}{c}\text { Free movement restricted } \\
\text { to: }\end{array}\end{array}$ & \multicolumn{2}{|c|}{ Once a year } & \multicolumn{2}{|c|}{$\begin{array}{c}\text { Regularly } \\
\text { Less frequently } \\
\text { than once a year }\end{array}$} & \multicolumn{2}{|c|}{$\begin{array}{c}\text { Once during } \\
\text { dog's life }\end{array}$} & \multicolumn{2}{|c|}{ Never } & \multicolumn{3}{c|}{ Total } \\
\hline & $\mathrm{n}$ & $\%$ & $\mathrm{n}$ & $\%$ & $\mathrm{n}$ & $\%$ & $\mathrm{n}$ & $\%$ & $\mathrm{n}$ & $\%$ \\
\hline Living quarters & 26 & 14.8 & 0 & 0.0 & 6 & 3.4 & 3 & 1.7 & 35 & 19.9 \\
\hline $\begin{array}{c}\text { Living quarters and } \\
\text { fenced outdoor area }\end{array}$ & 10 & 5.7 & 8 & 4.5 & 0 & 0.0 & 1 & 0.6 & 19 & 10.8 \\
\hline $\begin{array}{c}\text { Utility rooms and fenced } \\
\text { outdoor area }\end{array}$ & 9 & 5.1 & 0 & 0.0 & 3 & 1.7 & 9 & 5.1 & 21 & 11.9 \\
\hline Fenced outdoor area & 36 & 20.5 & 9 & 5.1 & 0 & 0.0 & 4 & 2.3 & 49 & 27.8 \\
\hline Non fenced outdoor area & 3 & 1.7 & 0 & 0.0 & 4 & 2.3 & 2 & 1.1 & 9 & 5.1 \\
\hline $\begin{array}{c}\text { The dog lives as a chained } \\
\text { one }\end{array}$ & 18 & 10.2 & 0 & 0.0 & 0 & 0.0 & 1 & 0.6 & 19 & 10.8 \\
\hline No any restrictions & 12 & 6.8 & 0 & 0.0 & 3 & 1.7 & 9 & 5.1 & 24 & 13.6 \\
\hline Total & 114 & 64.8 & 17 & 9.7 & 16 & 9.1 & 29 & 16.5 & 176 & 100.0 \\
\hline
\end{tabular}

Table 2. Preventive vaccination of cats against rabies in context to their living space

\begin{tabular}{|c|c|c|c|c|c|c|c|c|c|c|}
\hline $\begin{array}{c}\text { Cat's living space. } \\
\text { Free movement restricted } \\
\text { to: }\end{array}$ & \multicolumn{2}{|c|}{ Once a year } & \multicolumn{2}{|c|}{$\begin{array}{c}\text { Irregularly } \\
\text { Less frequently } \\
\text { than once a year }\end{array}$} & $\begin{array}{c}\text { Probably yes and } \\
\text { probably once } \\
\text { during cat's life }\end{array}$ & \multicolumn{2}{|c|}{ Never } & \multicolumn{3}{|c|}{ Total } \\
\hline & $\mathrm{n}$ & $\%$ & $\mathrm{n}$ & $\%$ & $\mathrm{n}$ & $\%$ & $\mathrm{n}$ & $\%$ & $\mathrm{n}$ & $\%$ \\
\hline Only living quarters & 4 & 4.7 & 0 & 0.0 & 6 & 7.0 & 0 & 0.0 & 10 & 11.6 \\
\hline $\begin{array}{c}\text { Not restricted but mainly } \\
\text { living quarters }\end{array}$ & 10 & 11.6 & 2 & 2.3 & 4 & 4.7 & 13 & 15.1 & 29 & 33.7 \\
\hline $\begin{array}{c}\text { Not restricted but mainly } \\
\text { outside living quarters }\end{array}$ & 0 & 0.0 & 8 & 9.3 & 4 & 4.7 & 14 & 16.3 & 26 & 30.2 \\
\hline $\begin{array}{c}\text { Areas outside living } \\
\text { quarters }\end{array}$ & 3 & 3.5 & 0 & 0.0 & 4 & 4.7 & 14 & 16.3 & 21 & 24.4 \\
\hline Total & 17 & 19.8 & 10 & 11.6 & 18 & 20.9 & 41 & 47.7 & 86 & 100.0 \\
\hline
\end{tabular}


Table 3. Veterinary health certificate possession procedures applied to dogs with different free movement restrictions

\begin{tabular}{|c|c|c|c|c|c|c|}
\hline \multirow{3}{*}{$\begin{array}{l}\text { Dog's living space. } \\
\text { Free movement restricted to: }\end{array}$} & \multicolumn{6}{|c|}{ Veterinary health certificate possession } \\
\hline & \multicolumn{2}{|c|}{ No } & \multicolumn{2}{|c|}{ Yes } & \multicolumn{2}{|c|}{ Total } \\
\hline & $\mathrm{n}$ & $\%$ & $\mathrm{n}$ & $\%$ & $\mathrm{n}$ & $\%$ \\
\hline Living quarters & 10 & 5.7 & 25 & 14.2 & 35 & 19.9 \\
\hline Living quarters and fenced outdoor area & 14 & 8.0 & 5 & 2.8 & 19 & 10.8 \\
\hline Utility rooms and fenced outdoor area & 4 & 2.3 & 17 & 9.7 & 21 & 11.9 \\
\hline Fenced outdoor area & 34 & 19.3 & 15 & 8.5 & 49 & 27.8 \\
\hline Non fenced outdoor area & 5 & 2.8 & 4 & 2.3 & 9 & 5.1 \\
\hline The dog lives as a chained one & 13 & 7.3 & 6 & 3.4 & 19 & 10.8 \\
\hline No any restrictions & 5 & 2.8 & 19 & 10.8 & 24 & 13.6 \\
\hline Total & 85 & 48.3 & 91 & 51.7 & 176 & 100 \\
\hline
\end{tabular}

Table 4. Veterinary health certificate possession procedures applied to cats with different free movement restrictions

\begin{tabular}{|c|c|c|c|c|c|c|}
\hline \multirow{2}{*}{$\begin{array}{c}\text { Cat's living space. } \\
\text { Free movement restricted to: }\end{array}$} & \multicolumn{5}{|c|}{ Veterinary health certificate possession } \\
\cline { 2 - 7 } & \multicolumn{2}{|c|}{ No } & \multicolumn{2}{|c|}{ Yes } & \multicolumn{2}{c|}{ Total } \\
\cline { 2 - 7 } & $\mathrm{n}$ & $\%$ & $\mathrm{n}$ & $\%$ & $\mathrm{n}$ & $\%$ \\
\hline $\begin{array}{c}\text { Only living quarters } \\
\text { Not restricted but mainly living } \\
\text { quarters }\end{array}$ & 19 & 22.1 & 10 & 11.6 & 29 & 33.7 \\
\hline $\begin{array}{c}\text { Not restricted but mainly outside } \\
\text { living quarters }\end{array}$ & 13 & 15.1 & 13 & 15.1 & 26 & 30.2 \\
\hline Areas outside living quarters & 18 & 20.9 & 3 & 3.5 & 21 & 24.4 \\
\hline Total & 56 & 65.1 & 30 & 34.9 & 86 & 100.0 \\
\hline
\end{tabular}




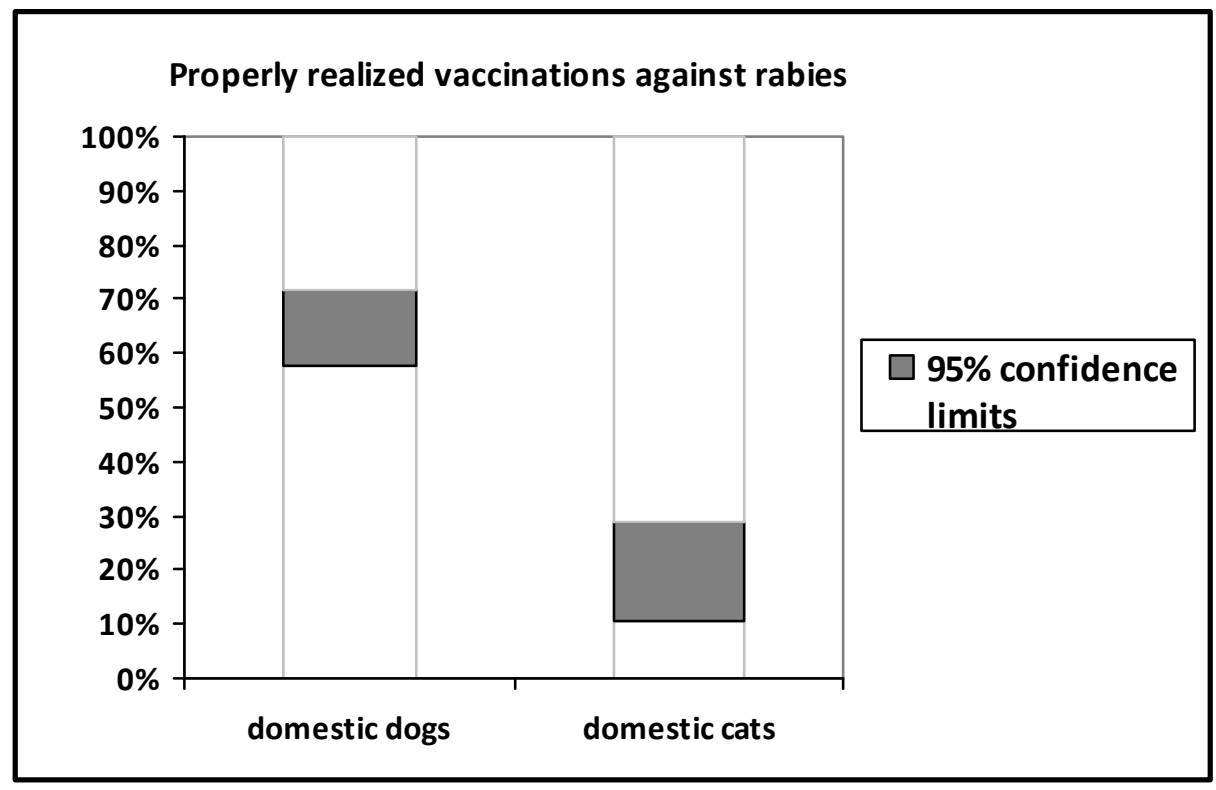

Figure 1. Percentages of cat and dogs owners properly realizing preventive domestic animals vaccinations against rabies

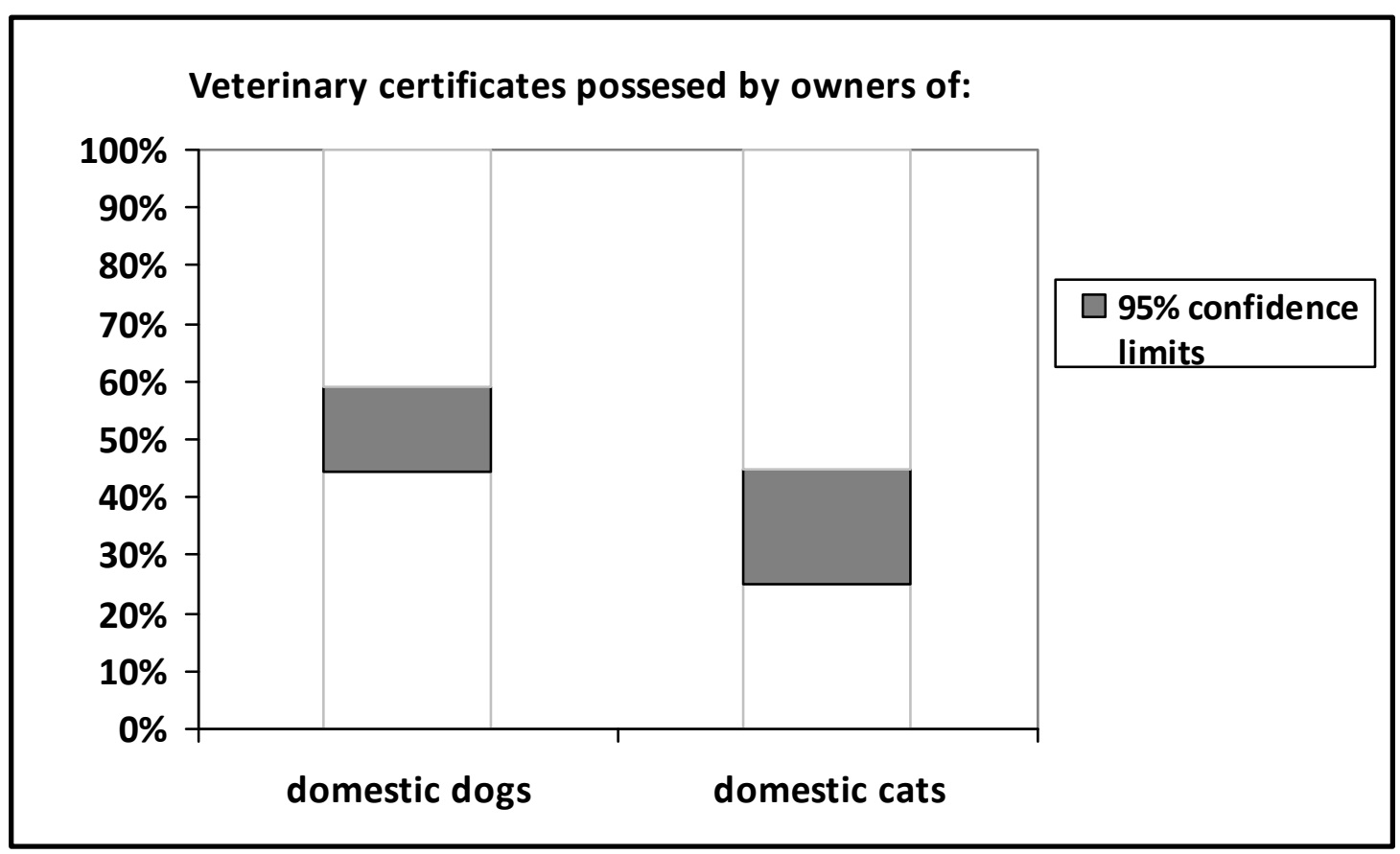

Figure 2. Veterinary certificates possessed by domestic cat and dog owners 